\title{
Molecular, Morphological, and Biological Differentiation between Anagrus virlai sp. n., an Egg Parasitoid of the Corn Leafhopper Dalbulus maidis (Hemiptera: Cicadellidae) in the New World, and Anagrus incarnatus from the Palaearctic Region (Hymenoptera: Mymaridae)
}

\author{
SV Triapitsyn ${ }^{1}$ iD, PF Rugman-Jones ${ }^{1}$, PS Tretiakov², E Luft Albarracin ${ }^{3}$, G Moya-Raygoza ${ }^{4}$, \\ RB QUERINO 5
}

${ }^{1}$ Dept of Entomology, Univ of California, Riverside, CA , USA

${ }^{2}$ Francisco J. Ayala, School of Biological Sciences, Univ of California, Irvine, CA, USA

${ }^{3}$ División Control Biológico, PROIMI-Biotecnología, San Miguel de Tucumán, Tucumán, Argentina

${ }^{4}$ Depto de Botánica y Zoología, CUCBA, Univ de Guadalajara, Zapopan, Jalisco, Mexico

${ }^{5}$ Embrapa Meio-Norte, Empresa Brasileira de Pesquisa Agropecuária, Teresina, Piauí, Brazil

\author{
Keywords \\ Mymaridae, Anagrus, taxonomy, Dalbulus \\ maidis, maize, egg parasitoid

\section{Correspondence \\ SV Triapitsyn, Dept of Entomology, Univ of California, Riverside, CA 92521, USA; serguei. triapitsyn@ucr.edu \\ Edited by Douglas Zeppelini - UEPB \\ Received 10 February 2018 and accepted 21 March 2018 \\ (C) Sociedade Entomológica do Brasil 2018}

\begin{abstract}
The common New World egg parasitoid of the corn leafhopper Dalbulus maidis (DeLong) (Hemiptera: Cicadellidae), an economically important pest of maize from Argentina to southern USA, has long been misidentified as the Palaearctic species Anagrus incarnatus Haliday or its synonym A. breviphragma Soyka (Hymenoptera: Mymaridae). Using a combination of genetic and morphometric methods, and available biological information, specimens reared from eggs of $D$. maidis in Argentina and Mexico, described and illustrated here as Anagrus (Anagrus) virlai Triapitsyn sp. n., are shown to be different from those of $A$. incarnatus from the Palaearctic region. Mitochondrial and nuclear ribosomal DNA sequence data provide clear evidence for the separation of the two species. Anagrus virlai is also known from Brazil, Colombia, Guadeloupe (France), and Guyana.
\end{abstract}

\section{Introduction}

Anagrus incarnatus Haliday, including its recent synonym A. breviphragma Soyka (Hymenoptera: Mymaridae) (Triapitsyn 2015b), has a broad distribution across the Palaearctic region (Triapitsyn 2015a [as A. breviphragma]). The true Old World $A$. incarnatus, fairly common in Europe, is an egg parasitoid of the green leafhopper Cicadella viridis (L.) (Hemiptera: Cicadellidae), several genera and species of Delphacidae (Hemiptera), and also Orthotylus virescens (Douglas \& Scott) (Hemiptera: Miridae) (Chiappini 1989, Chiappini et al 2015, Triapitsyn \& Berezovskiy 2004, Triapitsyn 2015a [as A. breviphragma]).

The corn leafhopper Dalbulus maidis (DeLong) is an economically important pest of maize from Argentina to the USA, and the Caribbean islands (Nault 1983, 1990, Triplehorn \& Nault 1985, Oliveira et al 2007, 2013, Virla et al 2013). One of its most common egg parasitoids in Argentina and Brazil was tentatively determined by Triapitsyn (1997) as A. breviphragma based solely on morphology, albeit with a comment that additional studies, including molecular ones, would be needed to demonstrate correctness of that identification. He has never been comfortable with his identification because specimens from the New World seemingly have a relatively shorter ovipositor and also do not share hosts with the true $A$. incarnatus from the Palaearctic region. They are, of course, also geographically isolated. Furthermore, the common host, $D$. maidis, of the New World Anagrus Haliday specimens, has likely co-evolved with its Zea spp. plant hosts (Nault \& Delong 1980, Nault 1990), which also have a New World origin, so it seemed unlikely that its 
main egg parasitoid would be the same species as that from Europe, i.e., A. incarnatus. While fresh, ethanol-preserved specimens from the New World were readily available, getting those from Europe had been difficult until a few specimens of the true $A$. incarnartus were recently collected in Finland and northwestern Russia, and properly preserved for DNA work. Triapitsyn (2015b) clarified the identity of the true A. incarnatus based on examination of its lectotype, illustrated here for the first time (Fig 1a, c). Here, we attempt to clarify the mistaken identity of the parasitoids from the Americas using both genetic and morphometric methods. Meanwhile, Hu and Triapitsyn (2016) described Anagrus (Anagrus) turpanicus Triapitsyn \& Hu from China. This parasitoid of the leafhopper Arboridia kakogawana (Matsumura), a pest of cultivated grapes in the Palaearctic region, is also morphologically similar to the Palaearctic $A$. incarnatus. DNA extracted from one of the paratypes of $A$. turpanicus prior to slide-mounting was successfully sequenced by the second author of the present paper, and it is used here for genetic comparison with both the true A. incarnatus from Europe and egg parasitoid of $D$. maidis from Argentina and Mexico. In Argentina, distribution and host associations of "A. breviphragma" and later "A. incarnatus" were reported by Luft Albarracin et al (2005), Virla et al (2013), and Luft Albarracin et al (2017). In Brazil, "A. breviphragma" was recorded parasitizing eggs of $D$. maidis in Sete Lagoas, Minas Gerais (Triapitsyn 1997), Piracicaba, São Paulo (Oliveira and Lopes 2000), and Teresina, Piauí (Querino et al 2017). Information on the egg parasitoids of $D$. maidis in Brazil including "A. breviphragma" was recently summarized by Querino et al (2017). In Mexico, "A. breviphragma" (more recently as "A. incarnatus") was reported as a main egg parasitoid of D. maidis (Moya-Raygoza et al 2012, 2014, Moya-Raygoza and Becerra-Chiron 2014) on Zea spp., including maize (MoyaRaygoza 2016) and wild teosintes (Moya-Raygoza and Triapitsyn 2017).

\section{Material and Methods}

Specimen collection. Essentially the same method was used to rear parasitoids of $D$. maidis in Argentina and Mexico, using sentinel eggs exposed in the cornfields free of pesticide applications during corn growing season (Virla et al 2009, Luft Albarracin et al 2017). To obtain sentinel eggs, 6-10 females of $D$. maidis were placed in cages $(35 \mathrm{~cm}$ high $\times$ $18 \mathrm{~cm}$ diameter) on leaves of potted maize plants in their vegetative stage for oviposition. After two (in Argentina) or three (in Mexico) days, the pots that contained sentinel host eggs were then exposed to parasitism in cornfields for three or four days (in Argentina) or five days (in Mexico). After five (in Mexico) or eight (in Argentina) days, the leaves with exposed eggs were cut from the plant, transported to a rearing room in the laboratory, and transferred to Petri dishes

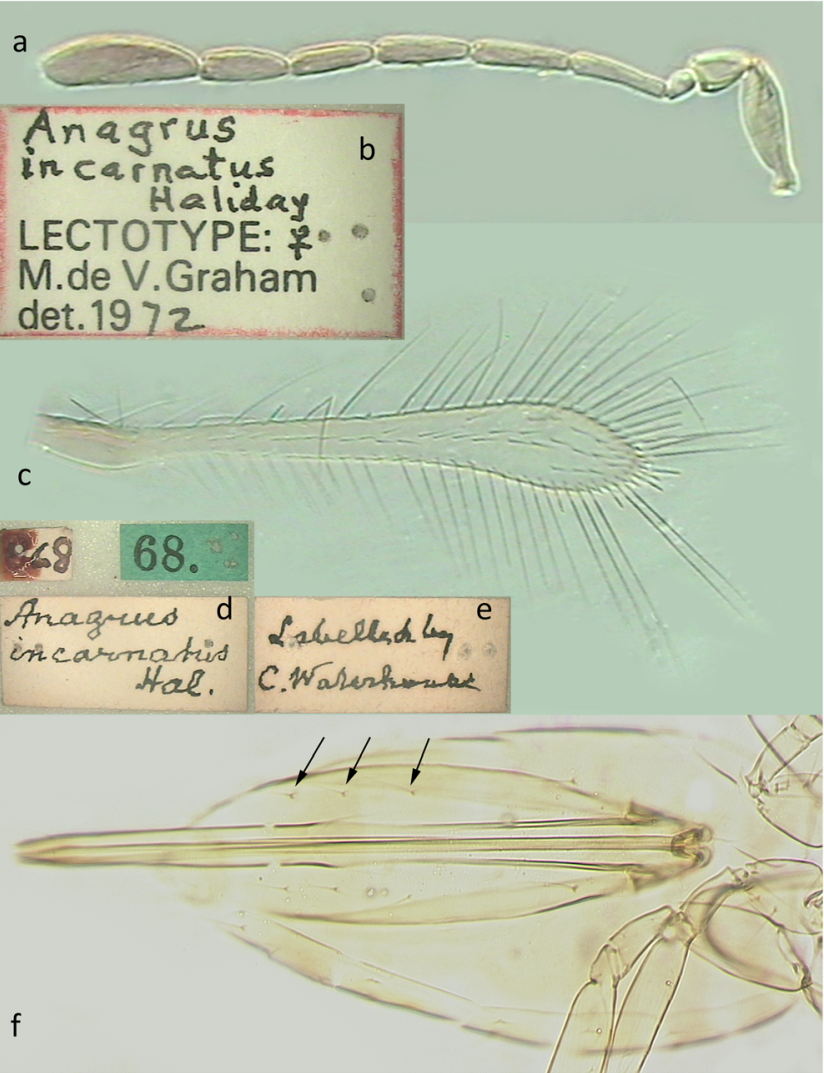

Fig 1 Anagrus incarnatus female: a antenna (lectotype), b lectotype designation label added by M. W. R. de V. Graham, c fore wing (lectotype), d, e numbers added by either F. Enock or C. O. Waterhouse and labels added by $\mathrm{C}$. O. Waterhouse, $\mathbf{f}$ metasoma (Lazio, Italy); arrows indicate setae on the second valvifer (= external plate of the ovipositor).

containing wet tissue paper on the bottom and covered with a polyethylene film to avoid desiccation of eggs and leaves, and to contain the emerging parasitoids. Parasitized eggs were checked daily to ensure leaf quality until emergence of all adult parasitoids. Emerging parasitoids were removed from the Petri dishes every day, labeled, and placed in $95 \%$ ethanol for storage at $-20^{\circ} \mathrm{C}$ until they were shipped to the first author. These specimens were used both for the molecular and morphometric analyses and also for taxonomic study (as type material). Specimens of $A$. incarnatus for the molecular analysis were collected either by sweeping (in Finland) or a Malaise trap (in Leningradskaya oblast', Russia). For the morphometric analyses, additional specimens of both species were studied from the collection of the Entomology Research Museum, Department of Entomology, University of California, Riverside, CA, USA.

Taxonomic studies. Morphological analysis is based only on females because males of these two species of Anagrus are similar. Other than in genitalic structure, males of Anagrus differ from females in the normal sexually dimorphic 
features: flagellum filiform, body color usually at least a little darker, and fore wing usually a little wider. Identification of males to species is often difficult or even impossible morphologically without rearing them together or associating them through collecting the sexes together at one time and place. Therefore, often it is not the species that is differentiated but only the females of that species.

Results of the genetic analysis were key in guiding the separation of the new species of Anagrus from the Old World $A$. incarnatus based on morphometry of females.

For the descriptions, the morphological terms of Gibson (1997) were used. All measurements (as length or length: width for the wings) are given in micrometers $(\mu \mathrm{m})$. Abbreviations used in the key and description are as follows: $\mathrm{F}=$ antennal funicular (female) or flagellar (male) segment; $\mathrm{mps}=$ multiporous plate sensillum or sensilla on the antennal flagellar segments (= longitudinal sensillum or sensilla or sensory ridge(s) of other authors).

Specimens from ethanol were dried using a critical point drier, then point-mounted and labeled. Selected specimens were further dissected and slide-mounted in Canada balsam. Slide mounts were examined under a Zeiss Axioskop 2 plus compound microscope (Carl Zeiss Microscopy, LLC, Thornwood, NY, USA) and photographed using the AutoMontage ${ }^{\circledR}$ system (Syncroscopy, Princeton, NJ, USA). Photographs were retouched where necessary using Adobe Photoshop ${ }^{\circledR}$ (Adobe Systems, Inc., San Jose, CA, USA).

Specimens examined are deposited in the following collections: CNC, Canadian National Collection of Insects, Arachnids and Nematodes, Ottawa, Ontario, Canada; CZUG, insect collection of Centro de Estudios en Zoología, Universidad de Guadalajara, Las Agujas, Zapopan, Jalisco, Mexico; EMNB, Embrapa Meio-Norte (Mid-North), Empresa Brasileira de Pesquisa Agropecuária, Teresina, Piauí, Brazil; IMLA, Fundación e Instituto Miguel Lillo, San Miguel de Tucumán, Tucumán, Argentina; MLPA, Museo de La Plata, La Plata, Buenos Aires, Argentina; NMID, the National Museum of Ireland - Natural History, Dublin, Ireland; and UCRC, Entomology Research Museum, Department of Entomology, University of California, Riverside, CA, USA.

DNA extraction, amplification, and sequencing. DNA was extracted from individual wasps using the "HotSHOT" method of Truett et al (2000), in a total volume of $80 \mu \mathrm{L}$. This nondestructive method allowed for the recovery and slidemounting of each specimen following extraction; each slide was then labeled with the assigned P. F. Rugman-Jones' primary molecular voucher PR number and UCRC database UCRC ENT number. Our sample included "incarnatus-like" wasps form both the Old World (Finland and Russia) and New World (Mexico and Argentina). DNA was also extracted from three further taxa in the incarnatus species group of Anagrus: A. avalae Soyka (UK, England, Kent Co., Sevenoaks, viii.2014, A. Polaszek [1 female, molecular voucher PR15-026, UCRC ENT 311795]); A. fennicus Soyka (RUSSIA, Moskovskaya oblast', Balashikhinskiy rayon, Chyornoe, 2.v.2016, A. K. Akhatov, emerged from old leaves of Carex sp. [1 female, molecular voucher PR16-512, UCRC ENT 311796]); and A. turpanicus (CHINA, Xinjiang, Turpan, Ya'er Guolecun, $42^{\circ} 56^{\prime} 43^{\prime \prime} \mathrm{N} 89^{\circ} 05^{\prime \prime} 37^{\prime} \mathrm{E}, 53 \mathrm{~m}$, 9.vii.2014, W.-q. Cao (Cao Wen-qiu), from eggs of Arboridia kakogawana (Matsumura) on table grape leaves [ 1 female paratype, molecular voucher PR15-021, UCRC ENT 249980]). Anagrus avalae and $A$. fennicus both have a pair of adnotaular setae on the midlobe of the mesoscutum, which are lacking in the members of the $A$. incarnatus species complex such as $A$. incarnatus, $A$. turpanicus, and the new species of Anagrus from the New World described herein.

The polymerase chain reaction (PCR) was employed to amplify the "barcoding" region of the mitochondrial cytochrome c oxidase subunit I gene (COI) using LCO1490 (5'GGTCAACAAATCATAAAGATATTGG-3') and HCO2198 (5'TAAACTTCAGGGTGACCAAAAAATCA-3'; Folmer et al 1994), as described in Rugman-Jones et al (2012). In a separate PCR, the internal transcribed spacer 2 (ITS2) region of nuclear ribosomal RNA (rRNA) was also amplified using the primers, 58SF (5'-GTGAACTGCAGGACACATGAAC-3') (Porter and Collins 1991) and ITS4 (5'-TCCTCCGCTTATTGATATGC-3') (White et al 1990), as described in Morse et al (2016). All reactions were performed in $25-\mu \mathrm{L}$ volumes on a Mastercycler ${ }^{\circledR}$ ep gradient $S$ thermocycler (Eppendorf North America Inc., New York, NY, USA). Amplification was confirmed by gel electrophoresis and PCR products were cleaned using a DNA Clean \& Concentrator ${ }^{T M}-5$ kit (Zymo Research Corporation, Irvine, CA, USA). Amplicons were direct sequenced in both directions at the Institute for Integrative Genome Biology, University of California at Riverside. Coincidentally, direct sequencing failed for the ITS2 amplicon of $A$. avalae (PR15-026), A. fennicus (PR16512), and $A$. turpanicus (PR15-021). ITS2 is part of the ribosomal cistron, of which there are hundreds of tandem copies in a typical eukaryote genome. Although rare, this creates potential for sequence variation among copies (Buckler et al 1997). To overcome this problem, sequencing of these three taxa was facilitated by cloning. The ITS2 PCR product was inserted into a plasmid vector (pGEM-T Easy Vector System; Promega) and plasmids were transformed in JM109 competent cells. For each taxon, three insertpositive clones were subsequently amplified and sequenced using M13 primers. A consensus of the three clones was then taken for each of these three species.

The parity of forward and reverse reads was checked using SEQUENCHER 4.9 (Gene Codes Corporation, Ann Arbor, $\mathrm{MI}$, USA) and priming regions were removed manually in BioEdit version 7.0.5.3 (Hall 1999). The online tool EMBOSS Transeq (Rice et al 2000) was used to translate all protein 
coding $\mathrm{COI}$ sequences into their amino acid chains, confirming the absence of indels and pseudogenes in the final dataset. All sequences were deposited in GenBank ${ }^{\circledR}$ (Benson et al 2008).

Genetic analysis. COI and ITS2 sequences were aligned separately using MAFFT version 7.050 (Katoh \& Standley 2013) and the Q-INS-i algorithm with default settings. Phylogenetic inference from ITS2 is typically problematic due to large interspecific differences that make alignment of this region difficult and somewhat ambiguous. Therefore, relationships among our specimens were empirically assessed based only on variation in COI. In turn, ITS2 sequences were examined "by eye" to determine if corroborating patterns were present.

The aligned $\mathrm{COI}$ dataset contained 18 terminal taxa (including outgroups), 587 nucleotide positions, and no gaps. Genetic variation among our sequences was estimated by calculating uncorrected $p$-distances between all possible sequence pairs, using MEGA version 6 (Tamura et al 2013). All ambiguous positions were removed for each sequence pair. MEGA was also used to investigate relationships among the sequences by constructing a neighbor-joining (NJ) tree based on the $p$-distances. Branch support was estimated using a bootstrap procedure with 1000 replicates.

\section{Results}

\section{Taxonomy}

\section{Anagrus (Anagrus) incarnatus Haliday 1833}

Anagrus incarnatus Haliday 1833: 347. Type locality: not specified in the original description (certainly in Europe, most likely in UK or Ireland). Lectotype female (Fig 1a-e), designated by Graham 1982: 200 (NMID), examined (Triapitsyn 2015b). Illustrated here are some of its non-original labels (Fig $1 b, d, e$ ), detailed information on which was given in Triapitsyn (2015b).

Anagrus breviphragma Soyka 1956: 25. Type locality unknown (certainly in Europe): (Chiappini 1989). Lectotype female (NHMW), de-facto designated by Chiappini 1989: 105106 (mentioned as holotype), examined by the senior author during several visits to the NHMW. Synonymized under A. incarnatus by Triapitsyn 2015b: 216.

Anagrus breviphragma Soyka: Chiappini 1989: 105-106 (synonymy, type information, diagnosis), Chiappini et al 1996: 558-559 (key, illustration), Triapitsyn 1997: 7 (in part: distribution), Chiappini et al 1999: 393-398 (genetic identity), Chiappini and Mazzoni 2000: 1663, 1670, 1672 (morphology of male genitalia), Triapitsyn 2000: 214-215 (in part: distribution, host associations), Chiappini 2002: 261-264 (development, illustrations); Chiappini \& Solinas 2002: 267271 (morphology), Triapitsyn \& Berezovskiy 2004: 15-16 (distribution, host associations), Triapitsyn 2015a: 12 (key), 19, 25 (illustrations), 27-28 (coded redescription of Palaearctic specimens only, distribution [in part], hosts [in part]), 33 (illustration), 41 (discussion), 42 (list).

Anagrus incarnatus Haliday: Chiappini 1989: 112-113 (lectotype only), Triapitsyn 2015b: 216 (taxonomic history, list of synonyms, type information, discussion).

Material examined. Measured specimens (all in UCRC). CHINA, Beijing, Fragrant Hills (Xiangshan) Park, 2324.vii.2002, M. L. Buffington [1 female]. ITALY: EmiliaRomagna, Piecenza Province, Piacenza, E. Chiappini: 20.ii.1984, emerged from an egg in Carex sp. [1 female]; Mortizza, 30.x.1985, emerged from egg of Cicadella viridis [2 females]. Lazio, Roma Province, Castelporziano Presidential Estate, Fosso di Trafusina, $41^{\circ} 46.670^{\prime} \mathrm{N}$ $12^{\circ} 24.751^{\prime} \mathrm{E}, 30 \mathrm{~m}, 11-12 . v i .2003$, M. Bologna, J. Munro, A. Owen, J. D. Pinto [1 female]. RUSSIA, Primorskiy kray, Ussuriyskiy rayon, Gornotayozhnoye, M. V. Michailovskaya: 8.vi.1999 [1 female]; 25-26.ix.1999 [1 female]; 1-10.viii.2000 [1 female]; 5-8.x.2000 [3 females]; 9-12.x.2000 [4 females]. Molecular vouchers (all in UCRC). FINLAND, Tavastia Proper, Janakkala, Kalpalinna, $60^{\circ} 55^{\prime} 37^{\prime \prime} \mathrm{N} 24^{\circ} 35^{\prime} 49^{\prime \prime} \mathrm{E}$, $101 \mathrm{~m}, 8 . v i i .2017$, S. V. Triapitsyn, V. Vikberg [1 female, PR17-594, UCRC ENT 251157]. RUSSIA, Leningradskaya oblast', Vsevolozhskiy rayon, Vaganovo, $60^{\circ} \mathrm{O}^{\prime} 24.5^{\prime \prime} \mathrm{N} 31^{\circ} \mathrm{O} 2^{\prime} \mathrm{O} 8.3^{\prime \prime} \mathrm{E}$, 25 m, 15-30.vi.2016, A. Knyshov [2 females, PR16-371 (UCRC ENT 495130) and PR16-374 (UCRC ENT 249949)].

Brief diagnosis (updated from Triapitsyn 2015a). Member of the incarnatus species complex of the incarnatus species group of Anagrus (Anagrus). Female antenna (Fig 1a) with F2 the longest funicular segment; mps on F3 (1), F4 (1), F5 (2), F6 (2), and clava (5); midlobe of mesoscutum without adnotaular setae; apex of fore wing disc with a distinct, large bare area at posterior margin subapically (Fig 1c); ovipositor (Fig 1f) 2.6-3.3× as long as protibia length; external plate of ovipositor with 3 setae.

Distribution. Palaearctic region from the UK to Japan. In addition to the 15 countries listed in Triapitsyn $(1997,2002)$, Triapitsyn \& Berezovskiy (2004), and Triapitsyn (2015a), we add Finland (new record, because all the previous records of this species from there were of $A$. incarnatosimilis Soyka).

Hosts. Cicadella viridis (Cicadellidae), Conomelus anceps (Germar), Dicranotropis hamata (Boheman), Muellerianella fairmairei (Perris) (Delphacidae), and Orthotylus virescens (Douglas \& Scott) (Miridae) (Moratorio \& Chiappini 1995, Triapitsyn \& Berezovskiy 2004, Chiappini et al 2015, 
Triapitsyn 2015a [as A. breviphragma, from the Palaearctic region only]).

Biology. Biological traits and other aspects of $A$. incarnatus [as $A$. breviphragma] in Europe were studied by Moratorio and Chiappini (1995), Chiappini (2002), and Chiappini et al $(2012,2015)$. This species is a facultative gregarious parasitoid, with 5-8 adults emerging from larger leafhopper eggs, whereas only one adult develops in smaller planthopper (Delphacidae) eggs (Moratorio and Chiappini 1995, Chiappini et al 2015).

\section{Anagrus (Anagrus) virlai Triapitsyn, sp. $n$.}

Anagrus breviphragma Soyka (misidentifications): Triapitsyn 1997: 2 (key), 6-7 (illustrations of the specimens from Argentina, distribution [in part], host associations [in part], discussion); Oliveira and Lopes 2000: 265-267 (distribution and egg parasitism of $D$. maidis in Brazil), Triapitsyn 2000: 214-215 (key, distribution [in part], host associations [in part]), Virla 2001: 240-246 (host associations, biology), Triapitsyn 2002: 215 (key), 217 (distribution, host association), Luft Albarracin et al 2005: 258-259 (host association in Argentina), Luft Albarracin et al 2009: 5 (distribution and host associations in Argentina), Virla et al 2009: 508-509 (host associations, distribution in Mexico), Moya-Raygoza et al 2012: 107-110 (egg parasitism of D. maidis in Argentina and Mexico), Virla et al 2013: 4-5 (egg parasitism of D. maidis and distribution in Argentina), Moya-Raygoza et al 2014: 310 (host associations), Moya-Raygoza and Becerra-Chiron 2014: 927 (mentioned as egg parasitoid of D. maidis in Mexico), Moya-Raygoza and Triapitsyn 2015: 296-297 (host associations), Querino et al 2017: 124-126 (historical and biological information), 128 (brief diagnosis, distribution in Brazil, host associations), 129 (illustrations of female from Brazil) [pages differ in the Portuguese version].

Anagrus incarnatus Haliday (misidentifications): MoyaRaygoza 2016: 725-728 (host association in Mexico), MoyaRaygoza and Triapitsyn 2017: 694-696 (host association, distribution in Mexico, taxonomic notes on female, illustrations of female), Luft Albarracin et al 2017: 670-674 (host associations, key, distribution in Argentina, illustrations).

Type material. Holotype female, deposited in UCRC, on slide (Fig 2a) labeled: 1. "MEXICO: Jalisco Zapopan 20.viii.2009 G. Moya-Raygoza vial \#5"; 2. "Mounted by V. V. Berezovskiy 2014 in Canada balsam"; 3. "From eggs of Dalbulus maidis (DeLong and Wolcott) on maize, Zea mays spp. mays"; 4. "Anagrus breviphragma Soyka Det. S. TRIAPITSYN 2014"; 5. [magenta] "Anagrus (Anagrus) virlai Triapitsyn HOLOTYPE O"; 7. [barcode database label] "UCRC UCRC ENT 311846". The holotype is in good condition, dissected under 3

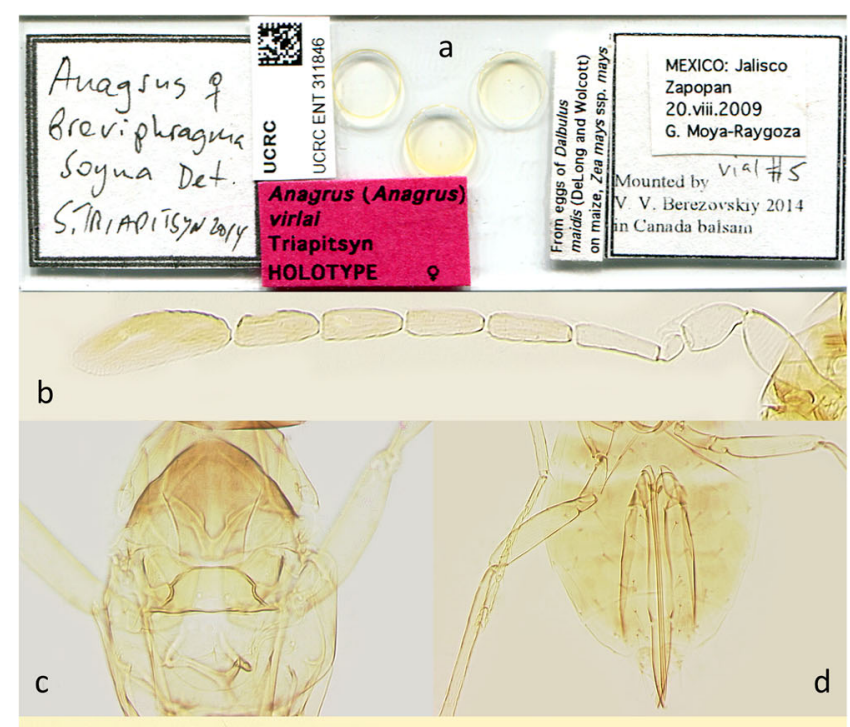

e

Fig 2 Anagrus virlai sp. n. female: a slide (holotype), b antenna (holotype), c mesoscutum (paratype from Las Talitas, Tucumán, Argentina), d metasoma (paratype from San Miguel de Tucumán, Tucumán, Argentina), e fore and hind wings (holotype).

coverslips. Along with some paratypes, the holotype was measured for the morphometric analysis.

Paratypes. Measured specimens (all on slides in UCRC). ARGENTINA: Córdoba: Barranca Yaco, 2-6.iv.2015, E. Luft Albarracin (from eggs of $D$. maidis on maize) [ 1 female, molecular voucher PR16-370, UCRC ENT 143822]. Río Cuarto, 715.xi.1994, E. G. Virla (from eggs of Delphacodes kuscheli Fennah on oat) [ 1 female]. Mendoza, San Rafael, xi.2005, E. Luft Albarracin (from eggs of Agallinae leafhoppers) [2 females]. Tucumán: El Manantial, 2649'50.2"S 6516'59.4" W, 495 m, i.2005, E. Luft Albarracin (from eggs of $D$. maidis on maize) [1 female]. Estación Aráoz, 21-28.v.2015, E. Luft Albarracin (from eggs of $D$. maidis on maize) [ 1 female, molecular voucher PR16-366, UCRC ENT 495104]. Las Talitas, iv.2005, E. Luft Albarracin (from eggs of $D$. maidis on maize) [1 female]. San Miguel de Tucumán, iii.2005, E. Luft Albarracin (from eggs of Chlorotettix fraterculus (Berg)) [1 female]. BRAZIL, Minas Gerais, Sete Lagoas, 5.vi.1996, D. L. Q. Santana (from eggs of $D$. maidis on maize) [2 females]. MEXICO, Jalisco, Zapopan, G. Moya-Raygoza (from eggs of D. maidis on maize): 10.ix.2008 [1 female]; 22.viii.2015 [1 female, molecular voucher PR15-507, UCRC ENT 249672]; 
25.viii.2015 [1 female, molecular voucher PR15-502, UCRC ENT 249950]; 23.ix.2015 [1 female, molecular voucher PR15503, UCRC ENT 249952]; 25.ix.2015 [1 female, molecular voucher PR15-506, UCRC ENT 249939].

Other paratypes (all on points). ARGENTINA, Tucumán: Ranchillos y San Miguel, 21-28.v.2015, E. Luft Albarracin (from eggs of $D$. maidis) [ 1 female, IMLA; 1 female, MLPA, 1 female, UCRC]. San Miguel de Tucumán, 8-12.iii.2015, E. Luft Albarracin (from eggs of $D$. maidis) [1 female, IMLA]. Tafí del Valle, i.2014, E. Luft Albarracin (from eggs of D. maidis) [1 female, IMLA; 1 female, MLPA]. MEXICO, Jalisco, Zapopan, $G$. Moya-Raygoza (from eggs of $D$. maidis on maize): 10.ix.2008 [10 females, 5 males: 2 females, 1 male, CNC; 2 females, 2 males, CZUG; 6 females, 2 males, UCRC].

Other paratypes (all on slides in UCRC). ARGENTINA: Córdoba, Río Cuarto, 7-15.xi.1994, E. G. Virla (from eggs of Delphacodes kuscheli Fennah on oat) [4 females, 1 male]. Salta, Cabeza de Buey, 17.v.1994, E. G. Virla (from eggs of D. maidis on maize) [3 females]. Tucumán: El Manantial, $26^{\circ} 49^{\prime} 50.2^{\prime \prime} \mathrm{S} 65^{\circ} 16^{\prime} 59.4^{\prime \prime} \mathrm{W}, 495 \mathrm{~m}, \mathrm{i} .2005, \mathrm{E}$. Luft Albarracin (from eggs of $D$. maidis on maize) [2 females]. San Miguel de Tucumán, iii.2004, E. Luft Albarracin, (from eggs of Chlorotettix sp. on maize) [ 1 female]. BRAZIL, Minas Gerais, Sete Lagoas, 5.vi.1996, D. L. Q. Santana (from eggs of D. maidis on maize) [4 females]. MEXICO, Jalisco: Ejutla, 2.ix.2015, G. Moya-Raygoza (from eggs of $D$. maidis on Zea mays ssp. parviglumis) [1 female]. Piedra Ancha, 10.x.2014, G. Moya-Raygoza (from eggs of $D$. maidis on perennial teosinte, Zea perennis) [1 female]. Zapopan, G. Moya-Raygoza (from eggs of $D$. maidis on maize): 10.ix.2008 [1 male]; $20 . v i i i .2009$ [1 male].

Other paratypes, molecular vouchers (all on slides in UCRC). ARGENTINA: Córdoba, Barranca Yaco, 2-6.iv.2015, E. Luft Albarracin (from eggs of $D$. maidis on maize) [ 1 female, PR16-369, UCRC ENT 249978]. Tucumán, Estación Aráoz, 2128.v.2015, E. Luft Albarracin (from eggs of D. maidis on maize) [4 females, PR15-291 (UCRC ENT 249932), PR15-292 (UCRC ENT 301942), PR16-367 (UCRC ENT 302271), PR16-368 (UCRC ENT 311831)]. MEXICO, Jalisco, Zapopan, G. MoyaRaygoza (from eggs of $D$. maidis on maize): 10.ix.2008 [3 females, PR15-027, PR15-037 and PR15-039 (extracts failed)]; 22.viii.2015 [1 male, PR15-505, UCRC ENT 311829].

Other, non-type, material examined. ARGENTINA: Córdoba: Barranca Yaco, 1-4.xii.2015, E. Luft Albarracin (from eggs of P. maidis on maize) [3 females, 1 male, IMLA]. Espinillos, 1215.xii.2016, E. Luft Albarracin (from eggs of $D$. maidis on maize) [2 females, 1 male, IMLA]. Río Cuarto, 12-15.xii.2016, E. Luft Albarracin (from eggs of D. maidis on maize) [3 females, 2 males, IMLA]. Tucumán: El Manantial, 24.xi.2011, E. Luft Albarracin (from eggs of $D$. maidis on maize) [2 females, IMLA]. La Virginia, 8-16.xii.2009, E. Luft Albarracin (from eggs of $D$. maidis on maize) [ 1 female, IMLA; 1 female,
MLPA]. Los Nogales, E. Luft Albarracin (from eggs of $D$. maidis on maize): 21-28.xii.2006 [4 females, 2 males, IMLA]; 812.ii.2007 [3 females, 2 males, IMLA]. San Miguel de Tucumán: [no date, likely in mid 1990s], E. G. Virla (from a laboratory colony at CIRPON on eggs of $D$. maidis, originally from Salta, Cabeza de Buey, 17.v.1994, E. G. Virla, from sentinel eggs of $D$. maidis on maize (Virla 2001)) [1 female, UCRC]; viii.2004, E. Luft Albarracin (from eggs of $D$. maidis on maize) [2 females, IMLA]; iii.2005, E. Luft Albarracin (from eggs of Chlorotettix fraterculus (Berg)) [1 female, UCRC (specimen lacks antennae)]; 20-26.xi.2010, E. Luft Albarracin [1 female, IMLA]; 13-23.x.2011, E. Luft Albarracin [1 female, IMLA]; 2-7.xii.2015, E. Luft Albarracin [2 females, 1 male, IMLA]; 17-22.ii.2016, E. Luft Albarracin [2 females, 2 males, IMLA]; 23-28.ii.2011, E. Luft Albarracin (from eggs of Peregrinus maidis (Ashmead) on maize) [1 female, 1 male, IMLA]; 4-12.xii.2014, E. Luft Albarracin [2 females, 1 male, IMLA]; 23-28.xi.2015, E. Luft Albarracin [3 females, 2 males, IMLA]. BRAZIL: Minas Gerais, Sete Lagoas, 5.vi.1996, D. L. Q. Santana (from eggs of $D$. maidis on maize) [ 1 female, UCRC (specimen is damaged)]. Piauí, Teresina, ii-iv.2013, A. R. Meneses (from sentinel eggs of $D$. maidis on maize) [15 females, EMNB]. MEXICO, Jalisco, Zapopan, 22.viii.2015, G. Moya-Raygoza (from eggs of $D$. maidis on maize) [10 females, CZUG]. These additional specimens are not included in the type series because many of them are either preserved in ethanol or a few are not mounted well enough; most of them have not been examined by the senior author.

Diagnosis. Member of the incarnatus species group of the nominate subgenus of Anagrus, as defined by Chiappini et al (1996). Female antenna (Fig 2b) with F2 the longest funicular segment; mps on F3 (1), F4 (1), F5 (1), F6 (2), and clava (5); midlobe of mesoscutum without adnotaular setae (Fig 2c); fore wing (Fig 2e) disc with a distinct, large subapical bare area; ovipositor 1.8-2.3 length of protibia.

Morphologically, $A$. virlai is most similar to the Palaearctic A. incarnatus, to which [as A. breviphragma] it keys in Triapitsyn (2015a) but the latter has a relatively longer ovipositor and $2 \mathrm{mps}$ on $\mathrm{F} 5$ of the female antenna. The morphometric analysis (Table 1 ) clearly separates $A$. virlai from A. incarnatus based on the ratio of ovipositor length to protibia length: at most $2.3 \times$ in $A$. virlai compared to at least $2.6 \times$ in $A$. incarnatus. The ovipositor length is also usually notably different, with just a slight overlap (Table 1) due to one small specimen of $A$. incarnatus from Beijing, China: that in $A$. virlai is shorter on average $(0.269 \pm 0.14 \mathrm{~mm})$ versus $0.353 \pm 0.03$ in $A$. incarnatus. All other measurements between both sexes of these two taxa overlap significantly and the observed morphological features are quite similar.

The new species is also similar to $A$. turpanicus from Xinjiang, China, in which, however, F2 of the female antenna is at most as long as F3 and always shorter than the following 
Table 1 Measurements (in micrometers, $\mu \mathrm{m}$ ) and ratios of some diagnostically important morphological features in slide-mounted females of Anagrus incarnatus from the Old World and Anagrus virlai from the New World (mean and standard deviation (SD) are given in parentheses, $n=14$ for both species).

\begin{tabular}{llllll}
\hline Species & $\begin{array}{l}\text { Body length range } \\
\text { (mean/SD) }\end{array}$ & $\begin{array}{l}\text { Ratio of fore wing length: } \\
\text { width (mean/SD) }\end{array}$ & $\begin{array}{l}\text { Ovipositor length } \\
\text { range (mean/SD) }\end{array}$ & $\begin{array}{l}\text { Ratio of ovipositor length: } \\
\text { protibia length (mean/SD) }\end{array}$ & $\begin{array}{l}\text { F2 length range } \\
\text { (mean/SD) }\end{array}$ \\
\hline Anagrus incarnatus & $529-891(676 / 82)$ & $7.2-10.5(8.7 / 0.9)$ & $290-412(353 / 30)$ & $2.6-3.3(2.9 / 0.2)$ & $50-86(70 / 10)$ \\
Anagrus virlai & $504-609(555 / 36)$ & $7.7-9.4(8.2 / 0.5)$ & $246-295(269 / 14)$ & $1.8-2.3(2.1 / 0.1)$ & $58-73(63 / 4)$ \\
\hline
\end{tabular}

funicular segments, whereas F5 bears just $1 \mathrm{mps}$ and the ovipositor is at most $2.4 \times(2.1-2.4 \times)$ length of protibia ( $\mathrm{Hu}$ \& Triapitsyn 2016). All three species also differ genetically.

Description. Female (holotype and paratypes). Body length of dry-mounted, critical point-dried paratypes 400-600 $\mu \mathrm{m}$, and of the slide-mounted paratypes 500-700 $\mu \mathrm{m}$. Body usually mostly light brown except anterior half or so of mesoscutum brown and frenum of scutellum and propodeum whitish, but often gaster either partially (basally only) or entirely brown; scape, pedicel and F1 yellowish or very light brown, rest of flagellum brown; legs mostly yellowish-brown, wings hyaline. Antenna (Fig 2b) with scape 2.8-3.3× as long as wide, with cross-ridges, 1.9-2.1× length of pedicel; F1 slightly longer than wide, a little less than half of pedicel length; F2 the longest funicular segment (slightly longer than more or less subequal following funicular segments); $\mathrm{mps}$ on F3 (1), F4 (1); F5 (1), and F6 (2); clava with $5 \mathrm{mps}, 2.8-3.6 \times$ as long as wide, usually slightly shorter than but rarely almost as long as combined length of F5 and F6. Midlobe of mesoscutum without adnotaular setae (Fig 2c). Fore wing (Fig 2e) 7.59.4× as long as wide, longest marginal seta $2.3-2.6 \times$ maximum wing width; distal macrochaeta 1.6-1.9x length of proximal macrochaeta; disc with several rows of setae in addition to admarginal rows of setae (1 complete row originating behind apex of venation and about 1 to 2 irregular rows in the broadest part of disc), leaving a distinct subapical bare area at posterior margin. Hind wing (Fig 2e) $26-27 \times$ as long as wide, longest marginal seta 6.6-7.0x maximum wing width; disc mostly bare except for incomplete admarginal rows of setae. Ovipositor (Fig 2d) not extending anteriorly to (and thus not overlapping) mesophragma in slide-mounted specimens, and only exserted a little beyond apex of gaster posteriorly (by 0.06-0.13× total ovipositor length). Second valvifers (= external plates of ovipositor), e.g., Chiappini (1989) and Chiappini et al (1996), each with 3 setae (Fig 2d). Ovipositor 1.8-2.3x length of protibia (2.2x in the holotype).

Measurements $(\mu \mathrm{m})$ of the holotype (as length or length: width). Mesosoma 236; gaster 282; ovipositor 257. Antenna: scape 79; pedicel 42; F1 17; F2 58; F3 55; F4 53; F5 54; F6 55; clava 106. Fore wing 551:67; longest marginal seta 173 . Hind wing 520:20; longest marginal seta 139.
Male (paratypes). Body length of the dry-mounted, critical point-dried paratypes $490-630 \mu \mathrm{m}$, and of the slide-mounted paratypes $615-730 \mathrm{~mm}$. Body mostly brown except frenum of scutellum and propodeum whitish, appendages light brown. Scape $2.7-3.2 \times$ as long as wide, F1 shorter and a little wider than following flagellomeres (Fig 3a). Fore wing (Fig 3b) 6.7$7.2 \times$ as long as wide. Genitalia (Fig 3c) length 133$142 \mu \mathrm{m}$.

Etymology. This new species is named in honor of our colleague and friend Eduardo G. Virla (Investigador de CONICET, Instituto de Entomología, Fundación Miguel Lillo, San Miguel de Tucumán, Argentina) who first reared it from eggs of D. maidis and also studied its biology (Virla 2001).

Distribution. Nearctic region: Mexico (Virla et al 2009, MoyaRaygoza et al 2012, 2014, Triapitsyn 2015a [as A. breviphragma]), Neotropical region: Argentina, Brazil, Colombia, Guadeloupe (France), and Guyana (Triapitsyn 1997, 2002, 2015a [as A. breviphragma]).

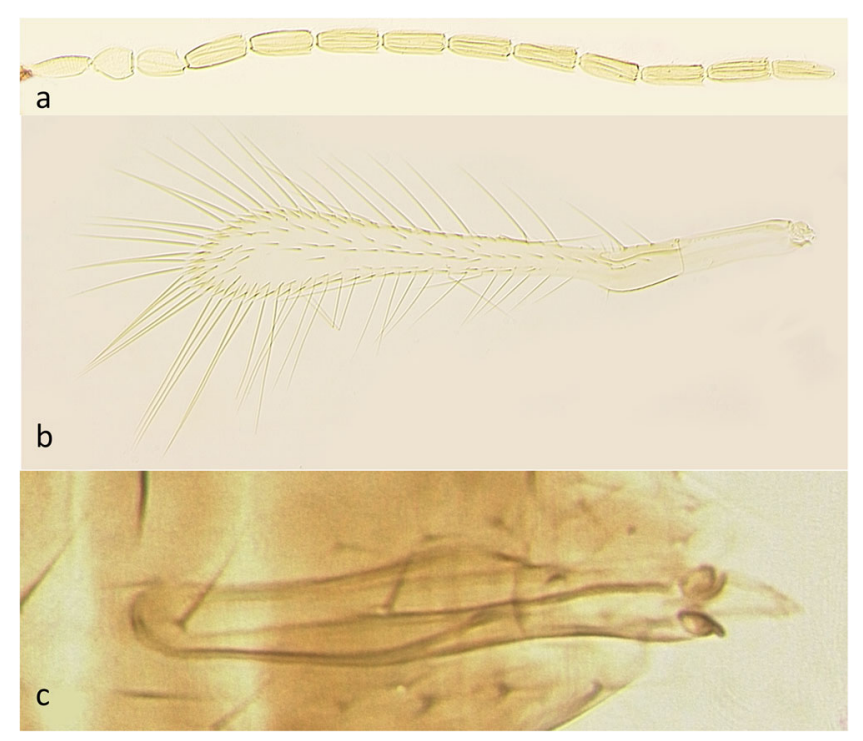

Fig 3 Anagrus virlai sp. n. male (paratypes from Zapopan, Jalisco, Mexico): $\mathbf{a}$ antenna, $\mathbf{b}$ fore wing, $\mathbf{c}$ genitalia. 
Table 2 Genetic divergence between (below diagonal) five species of Anagrus, based on a 587-bp fragment of the mitochondrial COI gene. Diagonal element shows intraspecific variation (Anagrus incarnatus and Anagrus virlai only). Average pairwise uncorrected $p$-distances calculated using MEGA6.

\begin{tabular}{lllccc}
\hline & incarnatus & virlai & avalae & fennicus & turpanicus \\
\hline incarnatus & 0.002 & & & & \\
virlai & 0.052 & 0.001 & & & \\
avalae & 0.060 & 0.060 & - & & \\
fennicus & 0.067 & 0.059 & 0.058 & - & \\
turpanicus & 0.060 & 0.052 & 0.063 & 0.079 & - \\
\hline
\end{tabular}

Hosts. Agalliana ensigera Oman, Chlorotettix fraterculus (Berg), Ciminius platensis (Berg), Dalbulus elimatus (Ball), Dalbulus maidis (DeLong), Dechacona missionum (Berg), Exitianus obscurinervis (Stål), Hortensia similis (Walker), Xerophloea viridis (Fabricius) (Cicadellidae), as well as Delphacodes kuscheli Fennah and Peregrinus maidis (Ashmead) (Delphacidae) (Triapitsyn 1997, Virla 2001; Luft Albarracin et al 2009, Virla et al 2009, Moya-Raygoza et al 2012, 2014, Triapitsyn 2015a, Querino et al 2017 [as A. breviphragma], Luft Albarracin et al 2017 [as A. incarnatus]).

Biology. In eggs of $D$. maidis, $A$. virlai always develops as a solitary parasitoid (Virla 2001), as it does in those of its other leafhopper and planthopper hosts known in Argentina (E. Luft
Albarracin, unpublished). Virla (2001) provided a detailed account of its other biological traits using eggs of $D$. maidis as host.

Results of the molecular analyses

Sequences of the $\mathrm{COI}$ gene provided strong evidence that $A$. virlai is distinct from $A$. incarnatus. Two haplotypes were identified for each species, with those from Old World, i.e., A. incarnatus, being $5.2 \%$ divergent from those from the New World, i.e., A. virlai, based on uncorrected $p$-distances (Table 2, Fig 4). This compared favorably with levels of divergence between other accepted species in the incarnatus species group (Table 2, Fig 4). In contrast, variation within each of the two species (A. incarnatus and $A$. virlai) was very low (Table 2). Specimens of $A$. virlai from Mexico $(n=5)$ all shared a single haplotype which differed at only a single nucleotide position from the second haplotype, shared by all specimens from Argentina ( $n=7$; Fig 4). However, this substitution ( $T$ to $G$ at position 58 ) resulted in a non-synonymous change in the coded amino acid chain (from serine to alanine). Similarly, the COI nucleotide sequence of the $A$. incarnatus specimen from Finland (PR17-594) differed from that shared by the two specimens from Russia at only two positions (342 and 384). In this case, both are considered to be synonymous changes.

The patterns found in the mitochondrial $\mathrm{COI}$ sequences were also repeated in the nuclear ribosomal ITS2 locus. The ITS2 amplicon from all $12 A$. virlai specimens was 638 bp long,
Fig 4 Relationships among the sequences of a 587-bp fragment of $\mathrm{COI}$ from five species of Anagrus. Optimal unrooted NJ tree with the sum of branch length $=0.11945095$. The percentage of replicate trees in which the associated taxa clustered together in the bootstrap test (1000 replicates) are shown next to the branches and the tree is drawn to scale, with branch lengths indicating uncorrected $p$-distance.

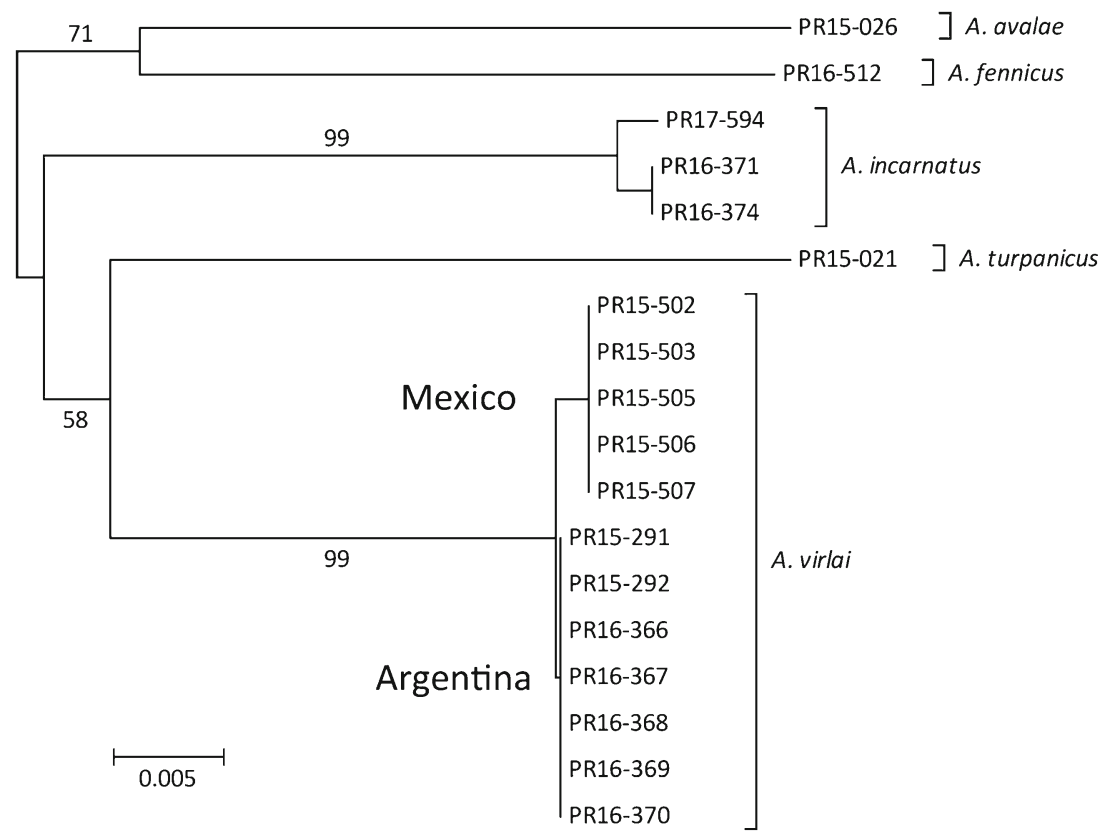


whereas that from three $A$. incarnatus specimens showed a small amount of length variation (613-621 bp), as a result of differing numbers of repeats at several poly-A or poly-T sites (Table 3). The MAFFT alignment of $A$. incarnatus and $A$. virlai sequences resulted in a matrix with 658 nucleotide positions, typified by large numbers of substitutions and indels between the two species (Table 3). Within $A$. virlai, the ITS2 sequence differed very slightly between specimens from Mexico and

Table 3 MAFFT alignment of ITS2 sequences highlighting the differences between Anagrus incarnatus (A. inc.) and Anagrus virlai. The aligned matrix contains 658 positions and variable positions (indels and substitutions) are in bold and designated by asterisks. Intraspecific variation between Anagrus virlai from Argentina and Mexico is further highlighted with shading.

\begin{tabular}{|c|c|}
\hline & $\cdots|\cdots|_{10} \cdots|\cdots|_{20} \cdots|\cdots|_{30} \cdots|\cdots|_{40} \cdots|\cdots|_{50} \cdots|\cdots|_{60} \cdots \mid$ \\
\hline A. inc. PR17-594 & ATCGACATTT CGAACGCACA TTGCGGTCCA CGGATTTAAT TCCCGGACCA CGCCTGGCTG AGGGTCGTTT \\
\hline A. inc. PR16-371 & ATCGACATTT CGAACGCACA TTGCGGTCCA CGGATTTAAT TCCCGGACCA CGCCTGGCTG AGGGTCGTTT \\
\hline A. inc. PR16-374 & ATCGACATTT CGAACGCACA TTGCGGTCCA CGGATTTAAT TCCCGGACCA CGCCTGGCTG AGGGTCGTTT \\
\hline A. virlai [Arg] & ATCGACATTT CGAACGCACA TTGCGGTCCA CGGATTTAAT TCCCGGACCA CGCCTGGCTG AGGGTCGTTT \\
\hline A. virlai [Mex] & ATCGACATTT CGAACGCACA TTGCGGTCCA CGGATTTAAT TCCCGGACCA CGCCTGGCTG AGGGTCGTTT \\
\hline & $\cdots|\cdots|_{80}$ \\
\hline A. & ATAAATATAA ACCAGACTGC TTGMGGGTGT TGCGT----T TTATRCGCAA CGCACCAAGC GATACCTGAA \\
\hline A. inc. PR16-371 & ATAAATATAA ACCAGACTGC TTGAGGGTGT TGCGT----T TTATACGCAA CGCACCAAGC GATACCTGAA \\
\hline A. inc. PR16-374 & ATAAATATAA ACCAGACTGC TTGAGGGTGT TGCGT----T TTATACGCAA CGCACCAAGC GATACCTGAA \\
\hline A. virlai [Arg] & ATAAATATAA ACCAGACTGC TTGCGGGTAT TGTGTATTTT TTATACGCAT TGCACCAAGC GATACCTGAA \\
\hline A. virlai [Mex] & ATAAATATAA ACCAGACTGC TTGCGGGTAT TGTGTATTTT TTATACGCAA CGCACCAAGC GATACCTGAA \\
\hline
\end{tabular}

A. inc. PR17-594

A. inc. PR16-371

A. inc. PR16-374

A. virlai [Arg]

A. virlai [Mex]

A. inc. PR17-594

A. inc. PR16-371

A. inc. PR16-374

A. virlai [Arg]

A. virlai [Mex]

A. inc. PR17-594

A. inc. PR16-371

A. inc. PR16-374

A. virlai [Arg]

A. virlai [Mex]

150

. $160^{\star \star \star \star \star \star \star \star \star \star \star \star ~}$

** ...|…

$80 \cdots|\cdots|$

$90 \cdots|\cdots|$

$200 \cdots|\cdots|$ |

CGTTCGCCGT TTT----- 160 TT -------- AAAAACGGTG TCGTTTGAAA TGATATGCAA GTTTCGGAGG CGTTCGCCGT TTT-----TT --.----- AAAAACGGTG TCGTTTGAAA TGATATGCAA GTTTCGGAGG

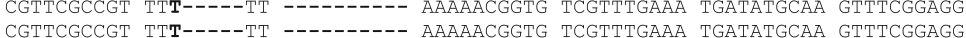
CGTTCGCCGT TTT----TT CGTTCGCCGT TTACGCGCTT CCGAGTGTCG AAAAACGGTG TCGTTTGAAA TGATATGCAA GTTTCGGAGG

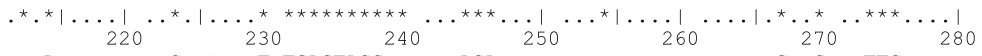
A-AATCGCTG ACCGAGAAAT TGAGTACG-- AACACAAGCT TGT-CTCGAA TTCTCTCTCG TGTTGAGCGA A-AATCGCTG ACCGAGAAAT TGAGTACGAA AACACAAGCT TGTCCTCGAA TTCTCTCTCG TGTTAAGCGA A-AATCGCTG ACCGAGAAAT TGAGTACGAA AACACAAGCT TGTCCTCGAA TTCTCTCTCG TGTTAAGCGA ATACTCGCTG ACGGAGAAA- -------A AACTTGAGCT TGT-CTCGAA TTCTCTTTCA TG---AGCGA ATACTCGCTG ACGGAGAAA- -------A AACTTGAGCT TGT-CTCGAA TTCTCTTTCA TG---AGCGA
ATACTCGCTG ACGGAGAAA- ------A AACTTGAGCT TGT-CTCGAA TTCTCTTTCG TG---AGCGA

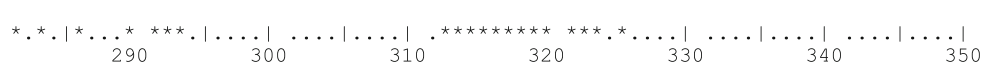
TAACGCCGCG GACGACGCGC GTGTGCAGGT TT--------tTTTACCA TGCGAATACA CGCGAATGCG TAACGCCGCG GACGACGCGC GTGTGCAGGT TT------ --TTTTACCA TGCGAATACA CGCGAATGCG TAACGCCGCG GACGACGCGC GTGTGCAGGT TT-------- --TTTTACCA TGCGAATACA CGCGAATGCG CAGCGTCGCA ATTGACGCGC GTGTGCAGGT TCGGTTTAAC TACTGTACCA TGCGAATACA CGCGAATGCG CAGCGTCGCA ATTGACGCGC GTGTGCAGGT TCGGTTTAAC TACTGTACCA TGCGAATACA CGCGAATGCG

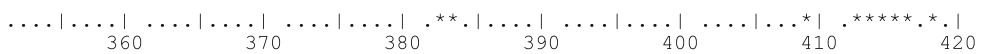
TCGGATGCAT TGCGTTCTCT TCCCGGAGCA T--AACAACG TGTCCGTGA CTTTCTTGCG T-----TTAT TCGGATGCAT TGCGTTCTCT TCCCGGAGCA T--AACAACG TGTCCGTGAG CTTTCTTGCG T-----TTAT TCGGATGCAT TGCGTTCTCT TCCCGGAGCA T--AACAACG TGTCCGTGAG CTTTCTTGCG T-----TTAT TCGAATGCAT TGCGTTCTCT TCCCGGAGCA TACAACAACG TGTCCGTGAG CTTTCTTGTG TATTTTTGAT

TCGAATGCAT TGCGTTCTCT TCCCGGAGCA TACAACAACG TGTCCGTGAG CTTTCTTGTG TATTTTTGAT

A. inc. PR16-371

A. inc. PR16-374

A. virlai $[\mathrm{Arg}$

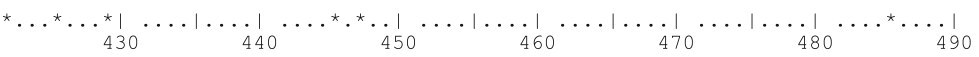

A. inc. PR17-594

A. inc. PR16-371

A. inc. PR16-374

A. virlai [Arg]

GCGCGATTAA GCGGACCGAT GTTAGACAGC ACTCCGAATG GGACAGAGAG TAGGCGTTGT CGTTATCGAG GCGCGATTAA GCGGACCGAT GTTAGACAGC ACTCCGAATG GGACAGAGAG TAGGCGTTGT CGTTATCGAG GCGCGATTAA GCGGACCGAT GTTAGACAGC ACTCCGAATg GGACAGAGA TAGGCGTTGT CGTTATCGAG ACGCAATTGA GCGGACCGAT GTTA-ATAGC ACTCCGAATG GGACAGAGA TAGGCGTTGT CGTTTTCGAG

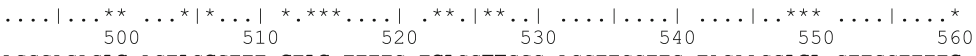
AGGGAGAGAC ACTACCGTTT GTAC-TTTTC TCACGTTGGC ACCTTCCTTG TACAACGAGA CTTGCTTTTG AGGGAGAGAC ACTACCGTTT TTACTTTTTC TCACGTTGGC ACCTTCCTTG TACAACGAGA CTTGCTTTTG AGGGAGAGAC ACTACCGTTT TTACTTTTTC TCACGTTGGC ACCTTCCTTG TACAACGAGA CTTGCTTTTG AGGGAGAGAC ACTACCGTTT TTACTTTTTC TCACGTTGGC ACCTTCCTTG TACAACGAGA CTTGCTTTT AGGGAGAG-- ACTGCTGTTT GT-TATTTTC TTGCGAAGGC ACCTTCCTTG TACAACGATG CTTGCTTTTA
AGGGAGAG-- ACTGCTGTTT GT-TATTTTC TTGCGAGGC ACCTTCCTTG TACAACGRT CTTGCTTTTA

A. inc. PR17-594

A. inc. PR16-371

A. inc. PR16-374

A. virlai [Arg]

A. virlai $[\mathrm{Mex}]$

A. inc. PR17-594

A. inc. PR16-371

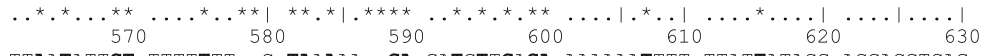
TTAATATTCT TTTTTTT--C TAAAAA--GA GATGTTGACA AAAAAATTTT TTATTATACG ACGACCTCAG TTAATATTCT TTTTTTTTTC TAAAAAAAGA GATGTTGACA AAAAAATTTT TTATTATACG ACGACCTCAG TTAATATTCT TTTTTTTTTC TAAAAA--AA GATGTTGACA AAAAAATTTT TTATTATACG ACGACCTCAC

$\begin{array}{llll}\text { A. } & \text { inc. PR16-374 } & \text { TIAATATTC } \\ \text { A. virlai [Arg] } & \text { TT-ACATTTC TTTTCTTTAC GGAGAATTGT GAAGGTAATG AAAAAA-TTT TTATCATACG ACGACCTCAG } \\ \boldsymbol{A} . \text { virlai [Mex] } & \text { TT-ACATTTC TTTTCTTTAC GGAGAATTGT GAAGGTAATG AAAAAA-TTT TTATCATACG ACGACCTCAG }\end{array}$

A. virlai [Mex]

A. inc. PR17-594

A. inc. PR16-371

A. inc. PR16-374

A. virlai $[\mathrm{Arg}]$

$\cdots|\cdots|{ }_{640} \cdots|\cdots| \ldots|\cdots| \cdots$

AGTAGGCGAG AATACCCGCT GAATTTAA

AGTAGGCGAG AATACCCGCT GAATTTAA

AGTAGGCGAG AATACCCGCT GAATTTAA

AGTAGGCGAG AATACCCGCT GAATTTAA

A. virlai [Mex]

AGTAGGCGAG AATACCCGCT GAATTTAA 
Argentina, with consistent nucleotide substitutions at three positions (120, 121, and 270 in the aligned matrix) and "partial" differences at two further positions (adenosine and guanine were characteristic of the aligned matrix positions 548 and 550, respectively, in Argentinian specimens, but were ambiguous [both $A$ or $G$ ] in four of the five Mexican specimens; Table 3). Sequences of the three other congeneric taxa confirmed them as distinct species, with multiple interspecific indels and substitutions ( $A$. avalae, 662 bp; A. fennicus, 645 bp; A. turpanicus, 563 bp; see GenBank accessions). Anagrus turpanicus is a sister species to $A$. virlai (Fig 4), and that is also corroborated by their morphological similarity; however, to truly test that apparent sister relationship, more loci (particularly nuclear ones) and more specimens would need to be analyzed.

\section{Discussion}

This study highlights the effectiveness of simple molecular techniques for aiding the diagnoses of cryptic species. The molecular results corroborated very well with those of the morphometric analysis resulting in the identification of $A$. virlai as a separate entity from $A$. incarnatus. Although crossing experiments may be considered the "gold standard" for drawing species boundaries (under the biological species concept), in their absence, the corroborating genetic discrimination (genotypic clustering; Mallet 1995) provided serves as a good proxy. Separation of $A$. virlai from $A$. incarnatus makes sense from the point of view of the likely co-evolution of $A$. virlai with its major host, the corn leafhopper $D$. maidis, and also the plant hosts of that leafhopper, Zea spp., all of which are definitely New World in origin. Thus, $A$. virlai is quite likely to occur throughout the distribution range of its major leafhopper host, $D$. maidis. According to Palomera et al (2012), no genetic variation among Mexican and Argentinian populations of $D$. maidis was found in the nuclear ribosomal ITS2 region whereas a low genetic variation was detected in the mitochondrial COI region. So, similar to the conclusions made by Palomera et al (2012) for D. maidis, our results could also be explained by the short evolutionary time scale, since both cultivated maize and the corn leafhopper, host of $A$. virlai, moved throughout the Americas only in recent millennia. The small amounts of variation in the COI and ITS2 sequences across our specimens of $A$. virlai (and across specimens of $A$. incarnatus) are well within accepted intraspecific tolerances, but may provide some suggestion of population structure across its geographic range (Fig 4, Table 3 ). This could be tested/confirmed with a larger sample size.

In the maize-producing countries of the Americas where $D$. maidis is an agricultural pest and a known vector of plant diseases that inflict serious damage to corn crop, one of the possible solutions is enhancement of its biological control. Further refinement in the taxonomy of $A$. virlai populations could be of particular importance.
Acknowledgments We thank Vladimir V. Berezovskiy (UCRC) for mounting specimens and Csaba Thuróczy (Kőszeg, Hungary) for kind permission to use his photographs of the lectotype of $A$. incarnatus. We are also grateful to the collectors listed in "Material examined" sections for donating specimens for our research.

\section{References}

Benson DA, Karsch-Mizrachi I, Lipman DJ, Ostell J, Wheeler DL (2008) GenBank. Nucleic Acids Res 36:D25-D30

Buckler ES, Ippolito A, Holtsford TP (1997) The evolution of ribosomal DNA: divergent paralogues and phylogenetic implications. Genetics $145: 821-832$

Chiappini E (1989) Review of the European species of the genus Anagrus Haliday (Hymenoptera Chalcidoidea). Boll Zool Agr Bachic Ser II 21:85-119

Chiappini E (2002) Anagrus and Oligosita: different strategies adopted to develop in the same host egg (Hymenoptera: Mymaridae, Trichogrammatidae). In: Melika G, Thuróczy C (eds) Parasitic wasps: evolution, systematics, biodiversity and biological control. International Symposium: "Parasitic Hymenoptera: taxonomy and biological control" (14-17 May 2001, Kőszeg, Hungary). Agroinform Kiadó és Nyomda Kft., Budapest, pp 261-266

Chiappini E, Mazzoni E (2000) Differing morphology and ultrastructure of the male copulatory apparatus in species-groups of Anagrus Haliday (Hymenoptera: Mymaridae). J Nat Hist 34:1661-1676

Chiappini E, Solinas C (2002) Ovipositor sensory structures of Anagrus breviphragma Soyka and their possible significance (Hymenoptera: Mymaridae). In: Melika G, Thuróczy C (eds) Parasitic wasps: evolution, systematics, biodiversity and biological control. International Symposium: "Parasitic Hymenoptera: taxonomy and biological control" (14-17 May 2001, Kőszeg, Hungary). Agroinform Kiadó és Nyomda Kft., Budapest, pp 267-271

Chiappini E, Triapitsyn SV, Donev A (1996) Key to the Holarctic species of Anagrus Haliday (Hymenoptera: Mymaridae) with a review of the Nearctic and Palaearctic (other than European) species and descriptions of new taxa. J Nat Hist 30(4):551-595

Chiappini E, Soressi L, Fogher C, Zanirato M (1999) Genetic identity and relationship between four Anagrus species (Hymenoptera: Mymaridae) using RAPD analysis. Entomol Exp Appl 144:311-316

Chiappini E, Salerno G, Berzolla A, lacovone A, Reguzzi MC, Conti E (2012) Role of volatile semiochemicals in host location by the egg parasitoid Anagrus breviphragma. Entomol Exp Appl 144:311-316

Chiappini E, Berzolla A, Oppo A (2015) Anagrus breviphragma Soyka short distance search stimuli. BioMed Res Int 2015(ID 727098):1-7

Folmer O, Black M, Hoeh W, Lutz R, Vriienhoek R (1994) DNA primers for amplification of mitochondrial cytochrome $C$ oxidase subunit 1 from diverse metazoan invertebrates. Mol Mar Biol Biotechnol 3:294-299

Gibson GAP (1997) Chapter 2. Morphology and terminology. In: Gibson GAP, Huber JT, Woolley JB (eds) Annotated keys to the genera of Nearctic Chalcidoidea (Hymenoptera). NRC Research Press, Ottawa, pp 16-44

Graham MWR de V (1982) The Haliday collection of Mymaridae (Insecta, Hymenoptera, Chalcidoidea) with taxonomic notes on some material in other collections. Proc R Ir Acad B82(12):189-243

Haliday AH (1833) An essay of the classification of the parasitic Hymenoptera of Britain, which correspond with the Ichneumones minuti of Linnaeus. Entomol Mag London 1:333-350

Hall TA (1999) BioEdit: a user-friendly biological sequence alignment editor and analysis program for Windows 95/98/NT. Nucleic Acids Symp Ser 41:95-98

Hu H-Y, Triapitsyn SV (2016) Anagrus turpanicus sp. n. (Hymenoptera: Mymaridae) from China, an egg parasitoid of Arboridia kakogowana [sic] (Hemiptera: Cicadellidae). Zootaxa 4161(4):573-578 
Katoh K, Standley DM (2013) MAFFT multiple sequence alignment software version 7: improvements in performance and usability. Mol Biol Evol 30:772-780

Luft Albarracin E, Virla E, Triapitsyn S (2005) Diversidad e incidencia de los parasitoides oofilos del vector del Achaparramiento (CSS), Dalbulus maidis (Hemiptera - Cicadellidae), en Tucumán, Argentina. In: [Proceedings] Trabajos presentados y resúmen de conferencias [Protección vegetal], VIII Congreso Nacional de Maíz, Rosario, Argentina, 16 al 18 de noviembre de 2005. AIANBA, Buenos Aires, pp 258-261

Luft Albarracin E, Triapitsyn SV, Virla EG (2009) Annotated key to the genera of Mymaridae (Hymenoptera: Chalcidoidea) in Argentina. Zootaxa 2129:1-28

Luft Albarracin E, Triapitsyn SV, Virla EG (2017) Egg parasitoid complex of the corn leafhopper, Dalbulus maidis (DeLong) (Hemiptera: Cicadellidae), in Argentina. Neotrop Entomol 46(6):666-677

Mallet J (1995) A species definition for the modern synthesis. Trends Ecol Evol 10:294-299

Moratorio MS, Chiappini E (1995) Biology of Anagrus incarnatosimilis and Anagrus breviphragma (Hymenoptera: Mymaridae). Boll Zool Agr Bachic Ser II 27(2):143-162

Morse JG, Rugman-Jones PF, Woolley JB, Heraty JM, Triapitsyn SV, Hofshi R, Stouthamer R (2016) Armored scales and their parasitoids on commercial avocados grown in California or imported from Mexico. J Econ Entomol 109(5):2032-2042

Moya-Raygoza G (2016) Effect of herbivore insect pest age on fecundity and attractiveness of egg parasitoids in maize and its wild relative, teosinte. Ann Entomol Soc Am 109(5):724-729

Moya-Raygoza G, Becerra-Chiron IM (2014) Overwintering biology of egg parasitoids of Dalbulus maidis (Hemiptera: Cicadellidae) on perennial grasses, volunteer maize, stubble, and drip-irrigated maize. Ann Entomol Soc Am 107(5):926-932

Moya-Raygoza G, Triapitsyn SV (2015) Egg parasitoids (Hymenoptera: Mymaridae and Trichogrammatidae) of Dalbulus quinquenotatus (Hemiptera: Cicadellidae), with description of a new species of Anagrus (Mymaridae) from Mexico. Ann Entomol Soc Am 108(3):289-298

Moya-Raygoza G, Triapitsyn SV (2017) Egg parasitoids of Dalbulus maidis on wild teosintes in Mexico. Southwest Entomol 42(3):691-700

Moya-Raygoza G, Luft Albarracin E, Virla EG (2012) Diversity of egg parasitoids attacking Dalbulus maidis (Hemiptera: Cicadellidae) populations at low and high elevation sites in Mexico and Argentina. Fla Entomol 95(1):105-112

Moya-Raygoza G, Renteria Cl, Luft Albarracin E, Virla EG (2014) Egg parasitoids of the leafhoppers Dalbulus maidis and Dalbulus elimatus (Hemiptera: Cicadellidae) in two maize habitats. Fla Entomol 97(1):309-312

Nault LR (1983) Origins in Mesoamerica of maize viruses and mycoplasmas and their leafhopper vectors. In: Plumb RT, Thresh JM (eds) Plant virus epidemiology: the spread and control of insect-borne viruses. Blackwell, Oxford, pp 259-266

Nault LR (1990) Evolution of an insect pest: maize and the corn leafhopper, a case study. Maydica 35(2):165-175

Nault LR, Delong D (1980) Evidence for co-evolution of leafhoppers in the genus Dalbulus (Cicadellidae: Homoptera) with maize and its ancestors. Ann Entomol Soc Am 73(4):349-353

Oliveira CM, Lopes JR (2000) Parasitóides de ovos da cigarrinha-domilho, Dalbulus maidis (DeLong. \& Wolcott) (Hemiptera, Cicadellidae), em Piracicaba. Rev Agric Paracicaba 75(2):263-270

Oliveira CM, Lopes JR, Camargo LE, Fungaro MH, Nault LR (2007) Genetic diversity in populations of Dalbulus maidis (DeLong and Wolcott) (Hemiptera: Cicadellidae) from distant localities in Brazil assessed by RAPD-PCR markers. Environ Entomol 36(1):204-212

Oliveira CM, Lopes JRS, Nault LR (2013) Survival strategies of Dalbulus maidis during maize off-season in Brazil. Entomol Exp Appl 147(2):141-153

Palomera V, Bertin S, Rodríguez A, Bosco D, Virla E, Moya-Raygoza G (2012) Is there any genetic variation among native Mexican and
Argentinian populations of Dalbulus maidis (Hemiptera: Cicadellidae)? Fla Entomol 95(1):150-155

Porter CH, Collins FH (1991) Species-diagnostic differences in a ribosomal DNA internal transcribed spacer from the sibling species Anopheles freeborni and Anopheles hermsi (Diptera: Culicidae). Am J Trop Med Hyg 45:271-279

Querino RB, Meneses AR, Luft Albarracin E, Oliveira C, Triapitsyn S (2017) Chapter 8. Biological control of Dalbulus maidis in Brazil. An overview of the parasitoids. In: Oliveira C, de Oliveira Sabato E (technical eds) Diseases in maize: insect vectors, mollicutes and viruses. Embrapa, Brasilia, DF, pp 119-138 (Capítulo 8. Controle biológico de Dalbulus maidis no Brasil. Uma visão geral sobre os parasitoides). In: Oliveira C, de Oliveira Sabato $E$ (eds técnicos) Doenças em milho: insetosvetores, molicutes e virus. Embrapa, Brasilia, DF, pp 121-140

Rice P, Longden I, Bleasby A (2000) EMBOSS: the European Molecular Biology Open Software Suite. Trends Genet 16:276-277

Rugman-Jones PF, Hoddle MS, Amrich R, Heraty JM, Stouthamer-Ingel $C E$, Stouthamer R (2012) Phylogeographic structure, outbreeding depression, and reluctant virgin oviposition in the bean thrips, Caliothrips fasciatus (Pergande) (Thysanoptera: Thripidae), in California. Bull Entomol Res 102:698-709

Soyka W (1956 [1955]) Überblick über das Genus Anagrus Haliday (Alaptidae - Mymaridae, Chalcidoidea, Hymenoptera). Entomol Nachr Wien 7:23-26

Tamura K, Stecher G, Peterson D, Filipski A, Kumar S (2013) MEGA6: Molecular Evolutionary Genetics Analysis version 6.0. Mol Biol Evol 30:2725-2729

Triapitsyn SV (1997) The genus Anagrus (Hymenoptera: Mymaridae) in America south of the United States: a review. Ceiba 38(1):1-12

Triapitsyn SV (2000 [1999]) A review of the species of Anagrus Haliday, 1833 (Hymenoptera: Mymaridae), collected by A. A. Ogloblin in Argentina. Russ Entomol J 8(3):213-222

Triapitsyn SV (2002) Descriptive notes on a new and other little known species of Anagrus Haliday, 1833 (Hymenoptera: Mymaridae) from the New World tropics and subtropics. Entomotropica 17(3):213-223

Triapitsyn SV (2015a) Taxonomy of the genus Anagrus Haliday (Hymenoptera: Mymaridae) of the world: an annotated key to the described species, discussion of the remaining problems, and a checklist. Acta Zool Lilloana 59(1-2):3-50

Triapitsyn SV (2015b) Taxonomic notes on Anagrus incarnatus Haliday and some other fairyflies (Insecta: Hymenoptera: Mymaridae) from the A. H. Haliday collection in the National Museum of Ireland. Bull Ir Biogeogr Soc 39:215-221

Triapitsyn SV, Berezovskiy VV (2004) Review of the genus Anagrus Haliday, 1833 (Hymenoptera: Mymaridae) in Russia, with notes on some extralimital species. Far East Entomol 139:1-36

Triplehorn BW, Nault LR (1985) Phylogenetic classification of the genus Dalbulus (Homoptera: Cicadellidae), and notes on the phylogeny of the Macrostelini. Ann Entomol Soc Am 78(3):291-315

Truett GE, Heeger P, Mynatt RL, Truett AA, Walker JA, Warman ML (2000) Preparation of PCR quality mouse genomic DNA with hot sodium hydroxide and Tris (HotSHOT). Biotech 29:52-54

Virla EG (2001) Notes on the biology of Anagrus breviphragma (Hymenoptera, Mymaridae), natural enemy of the corn leafhopper Dalbulus maidis (Hemiptera, Cicadellidae) and other plant diseases vectors in South America. Bol Sanid Veg Plagas 27:239-247

Virla EG, Luft Albarracin E, Moya-Raygoza G (2009) Egg parasitoids of Dalbulus maidis (Hemiptera: Cicadellidae) in Jalisco State, Mexico. Fla Entomol 92(3):508-510

Virla EG, Moya-Raygoza G, Luft Albarracin E (2013) Egg parasitoids of the corn leafhopper, Dalbulus maidis, in the southernmost area of its distribution range. J Insect Sci 13(10):1-7

White TJ, Burns T, Lee S, Taylor TJ (1990) Amplification and direct sequencing of fungal ribosomal RNA genes for phylogenetics. In: Innis MA, Gelfand DH, Sninsky JJ, White TJ (eds) PCR protocols: a guide to methods and applications. Academic Press, Burlington, pp 315-322 